\title{
Advanced Adrenal Gland Pheochromocytoma
}

National Cancer Institute

\section{Source}

National Cancer Institute. Advanced Adrenal Gland Pheochromocytoma. NCI Thesaurus.

Code C160853.

An adrenal gland pheochromocytoma that has spread extensively to other anatomical sites or is no longer responding to treatment. 